\title{
Developing a rapid, efficient and low cost method for rapid DNA extraction from arthropods
}

\author{
Desenvolvimento de um método rápido, eficiente e de baixo custo para extração de DNA \\ de artrópodos
}

\author{
Nicolás Oliveira Mega ${ }^{\mathrm{I}}$ Luís Fernando Revers ${ }^{\mathrm{II}}$
}

\begin{abstract}
Here, it is presented a rapid and efficient method to obtain good quality DNA from small samples of arthropod tissues generating low quantities of hazardous wastes. This new method was compared with another homemade protocol using phenol and other two commercial kits. The quality of DNA obtained was checked by spectrophotometer and evaluated by an AFLP assay. Low shearing DNA was obtained from all samples and the best readings were observed to DNA recollected with the new method. The AFLP assay indicated that DNA obtained with all methods were suitable for use in molecular biology techniques sensitive to contaminants. However, homemade protocols were more efficient in recollect DNA than commercial kits, without lose any quality of samples. Also, they were less time and fund consuming, with costs ten times cheaper than commercial kits. The quicker, less pollutant and cheaper protocol was the one described here (USD 0.52 per sample).
\end{abstract}

Key words: arthropod DNA, high quality DNA, molecular biology, AFLP.

\section{RESUMO}

Aqui, é apresentado um método rápido e eficiente para obtenção de DNA de boa qualidade a partir de pequenas amostras de tecidos de artrópodos, gerando pequenas quantidades de resíduos perigosos. Comparamos a eficiência do método com outro protocolo caseiro utilizando fenol e com dois kits comerciais. A qualidade do DNA obtido foi verificada em espectrofotômetro e avaliada por um ensaio de AFLP. Foi obtido DNA pouco fragmentado a partir de todas as amostras, mas as melhores leituras foram obtidas para o DNA extraído com o novo método. $O$ ensaio de AFLP indicou que os DNAs obtidos estavam adequados para uso em técnicas de biologia molecular sensíveis a contaminantes. Porém, os protocolos caseiros foram mais eficientes em extrair DNA do que kits comerciais, sem perder nenhuma qualidade na pureza das amostras. Além disso, eles foram mais rápidos e baratos, chegando a custar dez vezes menos que os kits comerciais. $O$ protocolo mais rápido, menos poluente e mais barato foi o descrito aqui (USD 0,52 por amostra).

Palavras-chave: DNA de artrópodos, DNA de alta qualidade, biologia molecular, AFLP.

\section{INTRODUCTION}

The analysis of genetic variation using deoxyribonucleic acids (DNA) polymorphisms has become an important tool to access evolutionary history, genetic diversity, identification of cell, bacteria, and virus strains, as well as some ecology issues and genetic improvement programs. The first step in DNA analyses is the extraction of nucleic acids from tissues or cells. Several methods for DNA extraction have been described for different groups and biological material (MOELLER et al., 1992; LODHI et al., 1994; YEATES et al., 1998; LEFORD \& DOUGLAS, 1999; SAMBROOK \& RUSSELL, 2001; BACKER et al., 2001; ROHLAND et al., 2004; GRACHEV et al., 2006; LEE \& PRYS-JONES, 2008; DE OLIVEIRA et al., 2009) and the most important

IPrograma de Pós-graduação em Genética e Biologia Molecular, Universidade Federal do Rio Grande do Sul (UFRGS); Departamento de Zoologia, 91501-970, Porto Alegre, RS, Brasil. E-mail: nicolas.mega @gmail.com. Autor para correspondência.

"Centro Nacional de Pesquisa de Uva e Vinho, Empresa Brasileira de Pesquisa Agropecuária, Bento Gonçalves, RS, Brasil. 
concern on these methods have been the quantity and quality of DNA. The quality of samples depends on biological material as well as on protocol followed (REINEKE et al., 1998; CHEN et al., 2008).

Homemade DNA extraction protocols are cheap and very efficient to recollect DNA from samples, but are usually time-consuming; commercial kits are generally very fast but too expensive and generate large quantities of contaminant wastes, such as beads, filters, columns and microcentrifuge tubes. Also, homemade DNA extraction protocols are less efficient in the removal of proteins/carbohydrates and other organic contaminants from samples or extraction solutions used, thus causing enzymatic inhibition in further molecular analysis. In these cases the use DNA cleanup steps are required, which can be time and fund consuming. An ideal protocol should optimize DNA yield, minimize degradation, and be efficient in terms of cost, time, labor, and supplies (CHEN et al., 2010).

REINEKE et al. (1998) evaluated several DNA extraction protocols using insect tissue samples and determined the quality of DNA recollected by Amplified Fragment Length Polymorphism (AFLP). The study also investigated the effect of additional cleanup steps on the improvement of DNA quality, concluding that the best protocols to obtain good quality DNA for AFLP are phenol or phenol-chloroform based methods, but for these protocols additional purification steps are recommend. Cationic detergent cetyltrimethyl ammonium bromide (CTAB)-based methods, as described in MOELLER et al. (1992), demonstrated to provide good quality DNA samples, using less hazardous chemicals, by combining its use with some proteinase and ribonuclease (RNAse), which can cause more fund consuming.

Here, it is described a method to obtain good quality DNA from small samples of freshly and frozen insect tissues. The method is CTAB-based and does not use phenol, a hazardous chemical and a contaminant in DNA samples. Sodium Chloride $(\mathrm{NaCl})$ has been used to remove polysaccharides (FANG et al., 1992), and polyvinyl pyrrolidone (PVP) to purge polyphenols from arthropods diet (MALIYAKAL, 1992). To improve DNA quality it was used cross-linked polyvinyl pyrrolidone (PVPP) to remove alkaloids, terpenoids, glycosides, phenols, phenazines polyketides and peptides, as well as protein and carbohydrate (HAAF et al., 1985). The main objective of this research was to develop a quick, cheap and less hazardous alternative to protocols available on literature and market.

\section{MATERIAL AND METHODS}

Species and tissue samples

Two flies, two butterflies, one moth, two spiders and three isopods species were used as biological material for test the protocol's efficiency to extract DNA from tissue samples. The species used were, respectively, Anastrepha fraterculus, Drosophila immigrans, Dryas iulia alcionea, Heliconius erato phyllis, Grapholita molesta, Paratrechalea azul, Paratrechalea ornata, Benthana cairensis, Balloniscus glaber, Balloniscus sellowi. All specimens were collected from nature and weighted. The tissue sources used for DNA extraction were whole body (flies, isopods and moth), head and thorax (butterflies) and cephalothorax (spiders). Each sample was frozen in liquid nitrogen and immediately crushed into a fine powder in $1.5 \mathrm{ml}$ sterile microcentrifuge tubes.

The DNA extraction protocol

Crushed tissues were mixed with PVPP (Sigma, P6755) in a proportion of 100mg of PVPP per $1 \mathrm{~g}$ of grinded tissue, $600 \mu \mathrm{L}$ of extraction buffer $(50 \mathrm{mM}$ Tris pH 8.0, 20mMEDTApH 8.0, $1.1 \mathrm{M} \mathrm{NaCl}, 0.4 \mathrm{MLiCl}$, $1 \%$ CTAB, 2\% PVP40 (Sigma), 0.5\% Tween 20, 0.2\% $\beta$ mercaptoethanol) in $1.5 \mathrm{ml}$ microcentrifuge tubes and mixed thoroughly. The tubes were incubated at $60^{\circ} \mathrm{C}$ for 25 minutes and inverted each 10 minutes for good solution of the crushed tissues with the buffer. The tubes were cooled at room temperature and $600 \mu \mathrm{L}$ of chloroform: isoamyl alcohol mixture (24:1) was added. The tubes were then mixed gently by inversion to form an emulsion during 4 minutes. After that the tubes were centrifuged (Eppendorf Centrifuge 5415R) at $10.600 \mathrm{~g}$ for 5 minutes at room temperature. The aqueous phase present in each tube $(\sim 500 \mu \mathrm{L})$ was transferred to a new $1.5 \mathrm{ml}$ microcentrifuge tube gently, to avoid DNA shearing. To each tube was added $250 \mu \mathrm{L}$ of $5 \mathrm{M} \mathrm{NaCl}$ and $750 \mu \mathrm{L}$ of cold $\left(-20^{\circ} \mathrm{C}\right)$ isopropanol. The solution was kept in the freezer at $-20^{\circ} \mathrm{C}$ for 20 minutes to improve precipitation nucleic acids. Samples were then centrifuged at 10.600g (Eppendorf Centrifuge 5415R) for 10 minutes at room temperature and the aqueous poured off. DNA pellets were washed with cold $\left(4^{\circ} \mathrm{C}\right)$ $76 \%$ ethanol $(1000 \mu \mathrm{L})$. After the washing step, the samples were spun quickly and the excess of ethanol removed with a micropipette. Washed DNA pellets were dried by leaving the tubes uncovered in a $37^{\circ} \mathrm{C}$ stove for 20 minutes. DNA samples were dissolved in $50 \mu \mathrm{L}$ TE (10mM Tris HCl pH 8.0, 0.1mM EDTA pH 8.0) and treated with $1 \mu \mathrm{L}$ of RNAase $\mathrm{A}\left(10 \mathrm{mg} \mathrm{mL}^{-1}\right)$ at $50^{\circ} \mathrm{C}$ for 20 minutes. 
Quality and quantification tests

Integrity of the DNA samples was analyzed in $0.8 \%$ ethidium bromide-stained agarose gels, using $1 \mathrm{~Kb}$ Ladder (Fermentas) as control for DNA shearing. Visual patterns of DNA samples were photographed under ultraviolet light and scanned with Stratagene EagleEye II still video system. The DNA samples were quantified using a spectrophotometer (GeneQuant PRO, Amersham Biosciences) in the absorbance spectrum for nucleic acids $(260 \eta \mathrm{m})$. To access DNA purity, $230 \mathrm{\eta m}$ and $280 \eta \mathrm{m}$ readings were recorded and compared with $260 \mathrm{~m}$ readings. The $230 \eta \mathrm{m}$ reading can indicate the presence of organic impurities and buffer contaminants, once phenols, carbohydrates, peptides, urea, thiocyanates, $\beta$-mercaptoethanol, humic acids and other buffer components absorb light at this wavelength (YEATES et al., 1998; SAMBROOK \& RUSSELL, 2001; HANSEN et al., 2007). The $280 \eta \mathrm{m}$ reading indicate the presence of proteins originated from the cells where the nucleic acids were extracted (YEATES et al., 1998; HANSEN et al., 2007), once tyrosine, tryptophan and phenylalanine amino acids are absorbed at this wavelength (SAMBROOK \& RUSSELL, 2001). It was considered as having good DNA quality, the samples which exhibited 260/230 and 260/280 $\eta \mathrm{m}$ rates higher than 1.7. Background correction was done using the $320 \mathrm{\eta m}$ reading to compensate the turbidity.

AFLP assay and evaluation of method's efficiency against other DNA extraction protocols

The quality of some DNA samples was also validated by an AFLP assay (VOS et al., 1995), a sensitive multi-step molecular technique based on the detection of genomic restriction fragments by polymerase chain reaction (PCR), which requires high quality DNA samples, free of organic compounds, proteins and RNA. During the AFLP assay, it was compared the AFLP profiles of the DNA samples obtained with protocol presented here with DNA samples obtained with another three protocols. The first one was a homemade sodium dodecyl sulfate (SDS)/phenol-chloroform based protocol, modified from RIED (2002). The other two protocols were guanidine hydrochloride/mini-column based protocols from commercial kits available on market for animal genomic DNA isolation: a silica membrane purification method from Macherey-Nagel $\mathrm{GmbH} \& \mathrm{Co}$. KG (NucleoSpin ${ }^{\circledR}$ Tissue, Ref. no 740952.10), and a resin membrane purification method from Norgen Biotek Corp. (Genomic DNA Isolation Kit, Ref no 24700) Additional information on DNA shearing and spectrophotometer absorbance were also provided for the DNA samples. All DNA samples used in this comparative test were obtained from Heliconius erato (Lepidoptera) specimens (numbered from $\mathrm{H} 01$ to $\mathrm{H} 08$ ) collected from a natural population near Porto Alegre, southern Brazil (lat-30.06681, log -51.122582), and were prepared as described for the other species. The selective amplification step of the AFLP assays were performed using four set of primers EcoRI+3 and MseI+3 nucleotides (set 1, EcoRI+ACC / MseI+CGC; set 2, EcoRI+AGG / MseI+CCG; set 3, EcoRI+ATA / MseI+CCT; and set 4, EcoRI+ACT / MseI+CCC) and visualized in silver stained $6 \%$ polyacrylamide denaturing gels according to CRESTE et al. (2001). It was considered as having good quality DNA the samples which produced clear AFLP patterns.

\section{RESULTS AND DISCUSSION}

\section{The DNA extraction protocol}

After the protocol application, DNA was obtained from all arthropod species and samples exhibited a transparent to very light color. In the $0.8 \%$ ethidium bromide-stained agarose gels the DNA samples revealed good quality (Figure 1). The DNAshearing effect was not prominent for any sample and only low smearing fragments were observed. This low shearing effect is expected, since the tissue samples were mechanically grinded and subjected to homogenization procedures. The RNAse treatment was efficient to eliminate RNA from the samples, once no RNA was observed in any sample.

The table 1 shows the results for the protocol's efficiency test with the different species. The yield of DNA recollected from the tissue samples shown a significant correlation between the weight of tissue sample used and the quantity of DNA recollected was observed $(r=0.842 ; \mathrm{P}<0.001)$. All samples tested shown high quality DNA after extraction procedure (Table 1). No significant amounts of proteins were detected in the samples, showing that protein removal was very efficient using the protocol presented here, without the necessity of using phenol or any other proteolytic method. Organic compounds presented in DNA samples also were inexpressive, dispensing the need of purification step after the extraction.

AFLP assay and evaluation of method's efficiency against other DNA extraction protocols

As observed for the other arthropod species, all DNA samples used for the AFLP assay revealed good quality. DNA samples obtained with the four methods compared shown similar results, but the yield of DNA recollected with the commercial kits was lower than homemade protocols. Wavelength readings 


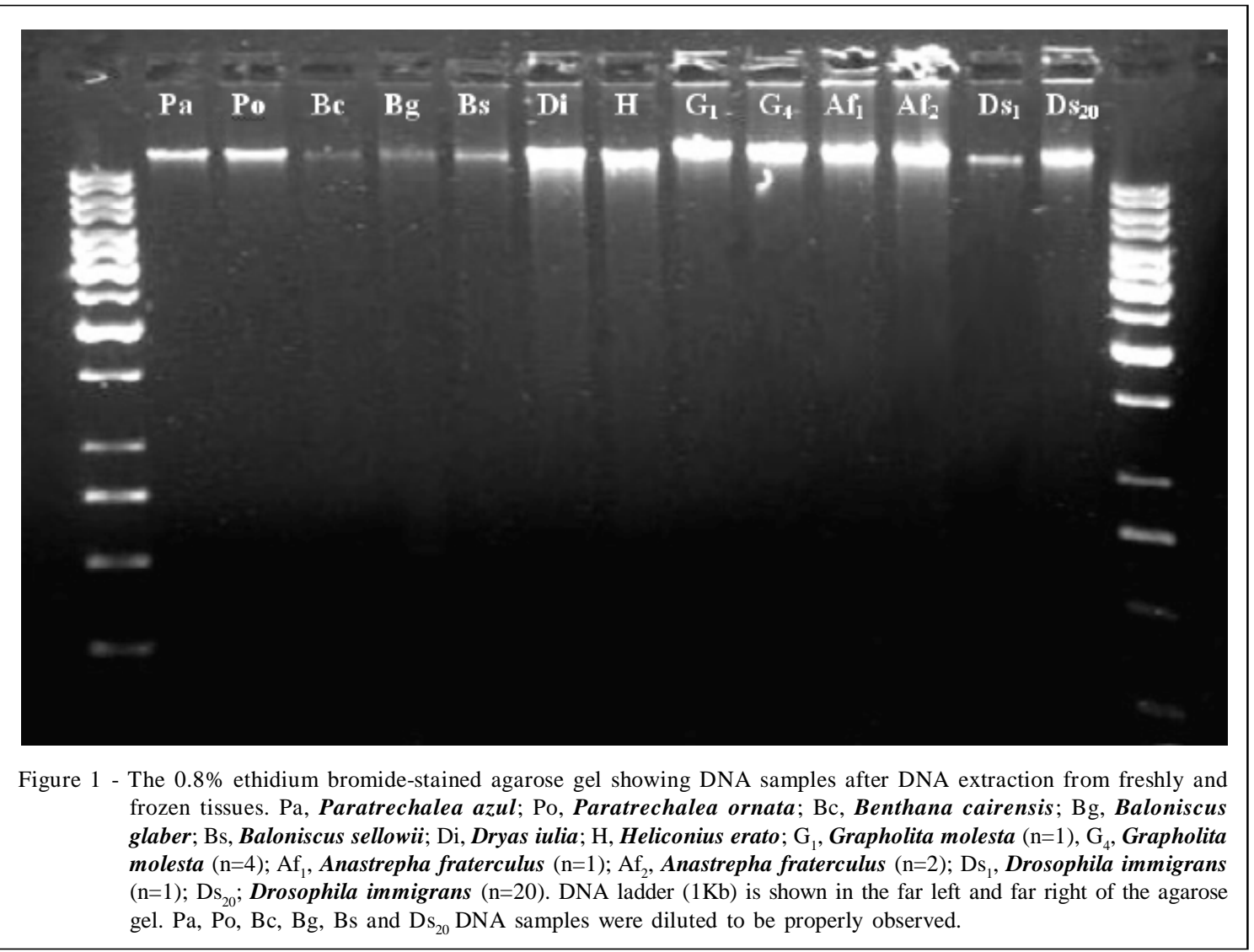

and wavelength rates also were very similar, excepting the samples H06 and H08, which were obtained with the commercial kits; those samples revealed some excess of organic impurities or contaminants (Table 1). No expressive amounts of proteins were observed in any sample.

The figure 2 shows the AFLPs patterns obtained for the DNA samples used in the AFLP assay. All four set of primers tested exhibited a great number of loci with good visualization. Overall, it was observed 251 distinguished loci, being 240 polymorphic. Regarding the DNA quality for molecular application, all four methods provided good quality, proving to be suitable for enzyme digestion, linkage and PCR, once AFLP has those three steps and is very sensitive to poor quality DNA samples (REINEKE et al., 1998; CHEN et al., 2008).

The results obtained with the AFLP assay indicate that the use of different methods may produce good quality DNA. Homemade protocols provide an alternative to low budget projects, but must be optimized to produce good results. Commercial kits are very convenient, but also too expensive. These statements become clear when time/fund consumption and toxic wastes produced are concerned (Table 2). The homemade protocol based on SDS/phenolchloroform extraction showed similar runtime and results to the $\mathrm{CTAB} / \mathrm{PVPP} /$ chloroform method presented here, and also was very inexpensive as well. Moreover, the use of phenol demands an additional step of organic solvent cleaning which generates higher amounts of contaminated wastes when compared with the method developed here. On the other hand, the commercial kits showed lower efficiency in recollect DNA from tissue samples when compared with the homemade protocols, without gain any advantages on samples purity. Despite having less time consuming, they were ten times more expensive than the homemade protocols. They did not generate hazardous wastes containing phenol and chloroform, dispensing the need of a fume hood to be applied, but the use of guanidine hydrochloride solutions also produces noxious wastes and some care on the disposal of residues should be taken as well. Scoring the benefits and costs of all protocols compared, the results indicate that the method presented here is the best choice to obtain good quality DNA. 
Table 1 - Analysis of concentration, wavelength absorbance readings and rates, and extraction efficiency for the biological samples used in the efficiency test and in the AFLP assay.

\begin{tabular}{|c|c|c|c|c|c|c|c|}
\hline \multirow{2}{*}{ Species/Sample $^{1}$} & \multirow{2}{*}{$\begin{array}{c}\text { DNA } \\
\text { concentration } \\
\left(\eta g \mu l^{-1}\right)\end{array}$} & \multicolumn{3}{|c|}{ Wavelength absorbance (A) ${ }^{2}$} & \multicolumn{2}{|c|}{ Wavelength rates ${ }^{3}$} & \multirow{2}{*}{ Extraction efficiency ${ }^{4}$} \\
\hline & & $230 \eta \mathrm{m}$ & $260 \eta \mathrm{m}$ & $280 \eta \mathrm{m}$ & $260 / 230 \eta \mathrm{m}$ & $260 / 280 \eta \mathrm{m}$ & \\
\hline \multicolumn{8}{|l|}{ Efficiency test } \\
\hline A. fraterculus $(\mathrm{n}=1)$ & 640.0 & 0.078 & 0.137 & 0.076 & 1.76 & 1.80 & 0.0023 \\
\hline A. fraterculus $(\mathrm{n}=2)$ & 1545.0 & 0.189 & 0.336 & 0.188 & 1.78 & 1.79 & 0.0028 \\
\hline B. cairensis $(\mathrm{n}=1)$ & 955.0 & 0.119 & 0.204 & 0.120 & 1.71 & 1.70 & 0.0029 \\
\hline B. $\operatorname{glaber}(\mathrm{n}=1)$ & 877.0 & 0.106 & 0.183 & 0.107 & 1.73 & 1.71 & 0.0019 \\
\hline B. sellowi $(\mathrm{n}=1)$ & 690.0 & 0.083 & 0.142 & 0.081 & 1.71 & 1.75 & 0.0021 \\
\hline D. iulia $(\mathrm{n}=1)$ & 1050.0 & 0.133 & 0.233 & 0.135 & 1.75 & 1.73 & 0.0040 \\
\hline D. immigrans $(\mathrm{n}=1)$ & 185.0 & 0.219 & 0.377 & 0.195 & 1.72 & 1.93 & 0.0037 \\
\hline D. immigrans $(\mathrm{n}=20)$ & 5580.0 & 0.263 & 0.570 & 0.284 & 2.17 & 2.01 & 0.0093 \\
\hline G. molesta $(\mathrm{n}=1)$ & 148.0 & 0.188 & 0.323 & 0.189 & 1.72 & 1.71 & 0.0015 \\
\hline G. molesta $(\mathrm{n}=4)$ & 785.0 & 0.095 & 0.164 & 0.093 & 1.73 & 1.76 & 0.0020 \\
\hline H. erato $(n=1)$ & 885.0 & 0.108 & 0.186 & 0.109 & 1.72 & 1.71 & 0.0033 \\
\hline P. $\boldsymbol{a z u l}(\mathrm{n}=1)$ & 2150.0 & 0.258 & 0.442 & 0.241 & 1.71 & 1.83 & 0.0014 \\
\hline P. ornata $(\mathrm{n}=1)$ & 630.0 & 0.078 & 0.134 & 0.073 & 1.72 & 1.84 & 0.0007 \\
\hline \multicolumn{8}{|l|}{ AFLP assay } \\
\hline H. erato $\mathrm{H} 01(\mathrm{n}=1)^{\mathrm{A}}$ & 649.0 & 0.873 & 1.492 & 0.929 & 1.91 & 1.77 & 0.0065 \\
\hline H. erato $\mathrm{H} 02(\mathrm{n}=1)^{\mathrm{A}}$ & 905.5 & 1.229 & 1.998 & 1.111 & 1.74 & 1.96 & 0.0082 \\
\hline H. erato $\mathrm{H} 03(n=1)^{B}$ & 753.0 & 0.803 & 1.532 & 0.797 & 1.94 & 1.95 & 0.0063 \\
\hline H. erato $\mathrm{H} 04(\mathrm{n}=1)^{\mathrm{B}}$ & 1020.0 & 1.381 & 2.154 & 1.215 & 1.61 & 1.85 & 0.0093 \\
\hline H. erato $\mathrm{H} 05(\mathrm{n}=1)^{\mathrm{C}}$ & 129.5 & 0.132 & 0.259 & 0.135 & 1.96 & 1.92 & 0.0026 \\
\hline H. erato $\mathrm{H} 06(\mathrm{n}=1)^{\mathrm{C}}$ & 92.0 & 0.199 & 0.191 & 0.111 & 0.96 & 1.77 & 0.0002 \\
\hline H. erato $\mathrm{H} 07(\mathrm{n}=1)^{\mathrm{D}}$ & 107.0 & 0.124 & 0.214 & 0.121 & 1.73 & 1.77 & 0.0053 \\
\hline H. erato $\mathrm{H} 08(\mathrm{n}=1)^{\mathrm{D}}$ & 55.5 & 0.210 & 0.130 & 0.087 & 0.58 & 1.63 & 0.0027 \\
\hline
\end{tabular}

${ }^{1}$ Numbers in brackets indicate the quantity of specimens used.

${ }^{2}$ Absorbance were measured by the optical density of the sample in relation to ultrapure distilled water.

${ }^{3}$ Wavelength rate higher than 1.7 indicates pure samples and lower than 1.7 indicate samples with significant levels of buffer/organic components $(260 / 230 \eta \mathrm{m})$ and proteins $(260 / 230 \eta \mathrm{m})$.

${ }^{4}$ In grams of DNA / grams of tissue.

${ }^{\text {A }}$ Mega e Revers' method (CTAB/PVPP/chloroform - described here).

${ }^{B}$ Ried's method (SDS/phenol-chloroform).

${ }^{\mathrm{C}}$ Kit 1 method (Macherey-Nagel GmbH \& Co. KG, NucleoSpin ${ }^{\circledR}$ Tissue - Ref. n⿳0 740952.10).

${ }^{D}$ Kit 2 method (Norgen Biotek Corp., Genomic DNA Isolation Kit - Ref. n⿳ํㅡㄹ 24700).

High yields of clean DNA were obtained from arthropod tissues by using the DNA extraction procedure presented here. The strategy of using $\mathrm{NaCl}$ to remove polysaccharides and PVP to purge polyphenols from arthropods' diet proved to be very efficient. The PVPP proved to be and proficient tool to isolate high quality DNA from tissue samples, especially by removing proteins and organic contaminants, without the need of further purification steps. It was also essential to keep apart cellular debris from the aqueous phase containing nucleic acid solution, by forming a compact and consistent interface.

Although the DNA extraction protocol developed here had shown promising results, some care must be taken to maximize the yield and quality of the DNA samples. First, the tissue sample must be completely dried before the grind procedure starts. The formation of ice crystals can prejudice the grinding procedure. Second, excess or lack of grinded tissue can generate samples with excess of proteins and organic compounds or residual buffer components, respectively. Although, as shown in the AFLP assay, the residual buffer components presented in the DNA samples did not interfere in the AFLP technique. Excess of tissue can cause pigmentation of DNA samples after extraction, but also increase the amount of DNA and other substances. The pigmentation does not affect the quality of DNA suitable to sensitive molecular techniques, but to obtain best results it is recommend increasing the dilution factor of DNA samples $(75-200 \mu \mathrm{l}$ of TE). According to the observations best results are achieved when $0.10-0.06 \mathrm{~g}$ of grinded tissue are used. 


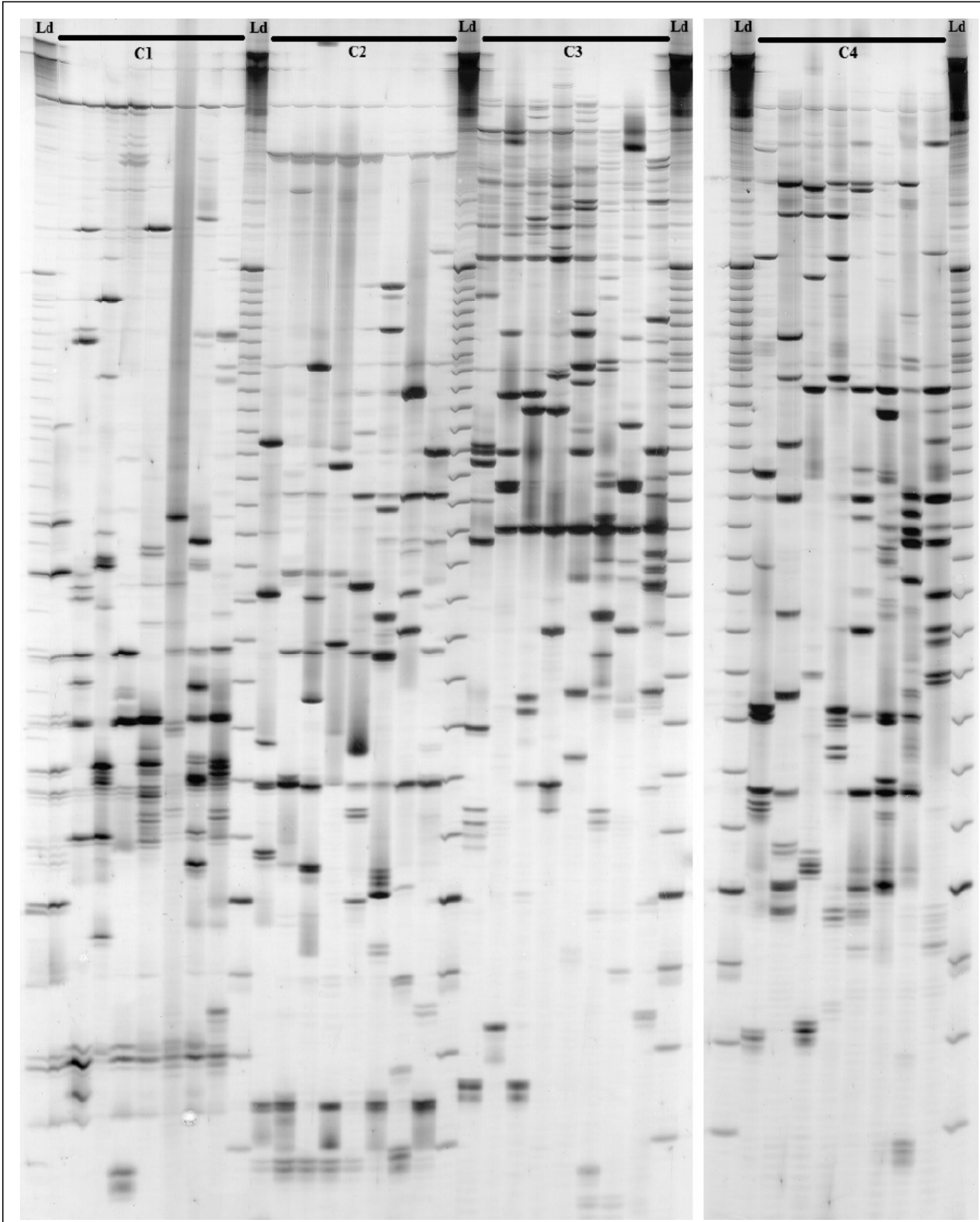

Figure 2 - Silver stained 6\% polyacrilamide denaturing gel showing the AFLP patterns of DNA samples tested six set of primers. C1. EcoRI+ACC / MseI+CGC; C2. EcoRI+AGG / MseI+CCG; C3. EcoRI+ATA / MseI+CCT; C4. EcoRI+ACT / MseI+CCC; Ld. 10 pb DNA Ladder. The sample sequence in each set of primer obeys the same order: H1 and H2 (Mega \& Revers' CTAB/PVPP/chloroform method - described here); H3 and H4 (Ried's SDS/phenol-chloroform method); H5 and H6 (Macherey-Nagel GmbH \& Co. KG, NucleoSpin ${ }^{\circledR}$ Tissue method- Ref. N ${ }^{\circ} 740952.10$ ); H7 and H8 (Norgen Biotek Corp., Genomic DNA Isolation Kit method - Ref. $\mathrm{N}^{\mathrm{o}}$ 24700).

\section{CONCLUSION}

It was concluded that the protocol presented here is a good method to obtain high quality
DNA without the necessity of further steps of proteolysis and purification. The protocol has an approximate cost of USD 0.52 per sample, including all chemicals and plastics, which is very inexpensive if 
Table 2 - A comparative of time, costs and hazardous wastes generated per sample with the four methods used to recollect DNA from fresh arthropod tissues.

\begin{tabular}{|c|c|c|c|}
\hline Method & Time to finish the protocol ${ }^{1}$ & $\begin{array}{l}\text { Cost per sample } \\
\quad(\text { USD })^{3}\end{array}$ & Hazardous wastes per sample \\
\hline $\begin{array}{l}\text { Mega } \\
\text { Revers, }\end{array}$ & $110 \mathrm{~min}$. & 0.52 & $\begin{array}{l}\text { One microtube contaminated with chloroform; } \sim 600 \mathrm{ul} \text { of } \\
\text { chloroform contaminated residues }\end{array}$ \\
\hline Ried's ${ }^{B}$ & 125 min. & 0.67 & $\begin{array}{l}\text { Two microtube contaminated with phenol and chloroform; } \sim 1.2 \\
\text { ml phenol and chloroform contaminated residues }\end{array}$ \\
\hline Kit $1^{\mathrm{C}}$ & 110 min. $^{2}$ & 5.10 & $\begin{array}{l}\text { One microtube, two collection tubes and one column } \\
\text { contaminated with guanidine hydrochloride; } \sim 1,7 \mathrm{ml} \text { of } \\
\text { guanidine hydrochloride contaminated residues }\end{array}$ \\
\hline Kit $2^{\mathrm{D}}$ & 85 min. $^{2}$ & 4.03 & $\begin{array}{l}\text { One microtube, one collection tube and one column } \\
\text { contaminated with guanidine hydrochloride; } \sim 1.3 \mathrm{ml} \text { of } \\
\text { guanidine hydrochloride contaminated residues }\end{array}$ \\
\hline
\end{tabular}

${ }^{1}$ Grinding tissue time and solution preparation time not considered.

${ }^{2}$ Sample incubation time of one hour.

${ }^{3}$ Calculated on February 2011, from lowest Brazilian market prices.

${ }^{\mathrm{A}} \mathrm{CTAB} / \mathrm{PVPP} / \mathrm{chloroform}$ - described here.

${ }^{\mathrm{B}} \mathrm{SDS} /$ phenol-chloroform.

${ }^{\text {C }}$ Macherey-Nagel GmbH \& Co. KG, NucleoSpin® Tissue (Ref. no 740952.10).

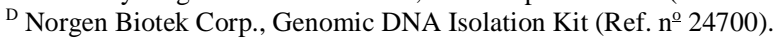

compared with the commercial kits. Also, hazardous wastes at the end of extraction procedure totaled one microcentrifuge tube with cellular debris and $600 \mu$ of chloroform and isoamyl alcohol mixture per sample. Thus, researchers from Agrarian and Biological Sciences may study arthropod DNA at low costs, generating lower quantities of toxic waste when compared with other methods and commercial kits available on market.

\section{ACKNOWLEDGMENTS}

The researchers are grateful to Alessandra Russi, Felippe Gomes, Gisele Passaia, Ivan Ceriotti, Rafaela Nalin and Vanessa Buffon for providing laboratory support, and Aline Quadros, Lisandra Robe, Luis E. Schmidt and Wilson Morandi Jr. for providing specimens for DNA extraction. This study was funded by CNPq, EMBRAPA Uva e Vinho and FAPERGS.

\section{REFERENCES}

BACKER, L.E. et al. A silica-based mitochondrial DNA extraction method applied to forensic hair shafts and teeth. Journal of Forensic Sciences, v.46, n.1, p.1-5, 2001.

CHEN, M. et al. Methodological comparison of DNA extraction from Holcocerrus hippophaecolus (Lepidoptera: Cossidae) for AFLP analysis. Forestry Studies in China, v.10, n.3, p.189-192, 2008. Available from: <http:// www.springerlink.com/content/h81720p74p82t467>. Accessed: Jun. 21 2011. doi: 10.1007/s11632-008-0035-5.

CHEN, H. et al. Evaluation of Five Methods for Total DNA Extraction from Western Corn Rootworm Beetles. PLoS One, v.5, n.8, p.e11963, 2010. Available from: <http://www.plosone.org/
article/info\%3Adoi\%2F10.1371\%2Fjournal.pone.0011963>. Accessed: Jun. 212011 doi:10.1371/journal.pone.0011963.

CRESTE, S. et al. Detection of single sequence repeat polymorphisms in denaturing polyacrilamide sequencing gels by silver staining. Plant Molecular Biology Reporter, v.19, p.299-306, 2001.

FANG, G. et al. A quick and inexpensive method for removing polysaccharides from plant genomic DNA. BioTechniques, v.13, n.1, p.52-56, 1992.

GRACHEV M.A. et al. A method for the isolation of pure DNA for PCR. Molecular Biology, v.40, n.1, p.159-161, 2006. Available from: <http://www.springerlink.com/content/ 075u65x3w8687374/>. Accessed: Jun. 21 2011. doi: 10.1134/ S0026893306010213.

HAAF, F. et al. Polymers of N-Vinylpyrrolidone: Synthesis. Characterization and Uses. Polymer Journal, v.17, n.1, p.143-152, 1985. Available from: <http://www.jstage.jst.go.jp/ article/polymj/17/1/143/_pdf>. Accessed: Jun. 212011. doi:10.1295/polymj.17.143.

HANSEN, T.O. et al. Collection of blood, saliva. and buccal cell samples in a pilot study on the Danish nurse cohort: comparison of the response rate and quality of genomic DNA. Cancer Epidemiology, Biomarkers \& Prevention, v.16, n.10, p.2072-2076, 2007. Available from: <http:// cebp.aacrjournals.org/content/16/10/2072.abstract>. Accessed: Jun. 21 2011. doi:10.1158/1055-9965.EPI-07-0611.

LEE, P.L.M.; PRYS-JONES, R.P. Extracting DNA from museum bird eggs, and whole genome amplification of archive DNA. Molecular Ecology Resources, v.8, n.3, p.551-560, 2008. Available from: <http://www3.interscience.wiley.com/cgi-bin/ fulltext/120090725/HTMLSTART>. Accessed: Jun. 212011. doi: $10.1111 / \mathrm{j} .1471-8286.2007 .02044 . x$. 
LEFORT, F.; DOUGLAS, G.C. An efficient micro-method of DNA isolation from mature leaves of four hardwood tree species Acer, Fraxinus, Prunus and Quercus. Annals of Forest Science, v.56, n.3, p.259-263, 1999. Available from: <http:/ /www.afs-journal.org/articles/forest/pdf/1999/03/AFS_00034312_1999_56_3_ART0008.pdf>. Accessed: Jun. 212011. doi: $10.1051 /$ forest: 19990308 .

LODHI, M.A. et al. A simple and efficient method for DNA extraction from Grapevine cultivars and Vitis species. Plant Molecular Biology Reporter, v.12, n.1, p.6-13, 1994.

MALIYAKAL, E.J. An efficient method for isolation of RNA and DNA from plants containing polyphenolics. Nucleic Acids Research, v.20, n.9, p.2381, 1992. Available from: <http:// www.ncbi.nlm.nih.gov/pmc/articles/PMC3 12364/pdf/ nar00083-0172.pdf>. Accessed: Jun. 21 2011. doi:10.1093/ nar/20.9.2381.

MOELLER E.M. et al. A simple and efficient protocol for isolation of high molecular weight DNA from filamentous fungi. fruit bodies. and infected plant tissues. Nucleic Acids Research, v.22, n.22, p.6115-6116, 1992.

OLIVEIRA, L.F.V. et al. Isolation of high quality DNA: a protocol combining "rennet" and glass milk. Electronic Journal of Biotechnology, v.12, n.2, p.1-6, 2009. Available from: <http://www.ejbiotechnology.info/index.php/ ejbiotechnology/article/view/v12n2-4/709>. Accessed: Jun. 21 2011. doi: 10.2225/vol12-issue2-fulltext-4.

REINEKE A. et al. Preparation and purification of DNA from insects for AFLP analysis. Insect Molecular Biology, v.7, n.1, p.95-99, 1998. Available from: <http:// www3.interscience.wiley.com/journal/119130668/abstract $>$. Accessed: Jun. 212011 . doi: 10.1046/j.13652583.1998.71048.x.

RIED, T. DNA preparation from fresh/frozen tissue. Bethesda: Section of Cancer Genomics, Genetics Branch, NCI, National Institutes of Health, MD, 2002. Protocols. Available on Internet from: http://www.riedlab.nci.nih.gov/publications/ DNA\%20Prep_TC\%20\%20High\%20Salt.doc.pdf. Online. Accessed: Jun. 212011

ROHLAND, N. et al. Nondestructive DNA extraction method for mitochondrial DNA analyses of museum specimens. Biotechniques, v.36, n.5, p.814-821, 2004. Available from: <http://www.biotechniques.com/BiotechniquesJournal/2004/ May/Nondestructive-DNA-extraction-method-formitochondrial-DNA-analyses-of-museum-specimens/ biotechniques-116773.html>. Accessed: Jun. 21 2011. doi $10.2144 / 3605 \mathrm{~A} 0814$.

SAMBROOK, J.; RUSSELL, D.W. Molecular cloning: a laboratory manual. Woodbury: Cold Spring Harbor Laboratory, 2001. 3v, 999p.

VOS, P. et al. AFLP: a new technique for DNA fingerprinting. Nucleic Acids Research, v.23, n.21, p.4407-4414, 1995.

YEATES, C. et al. Methods for microbial DNA extraction from soil for PCR amplification. Biological Procedures Online, v.1, n.1, p.40-47, 1998. Available from: <http:// www.springerlink.com/content/c3lw5258r3378rg7/>. Accessed: Jun. 21 2011. doi: 10.1251/bpo6. 